\title{
Development and Validation of a Loop-Mediated Isothermal Amplification (LAMP) Assay for Rapid Detection of Glaesserella (Haemophilus) parasuis
}

\author{
Veronika Pilchová $^{1}$, Diana Seinige ${ }^{2}$, Isabel Hennig-Pauka ${ }^{3} \mathbb{D}$, Kathrin Büttner ${ }^{4}$, Amir Abdulmawjood ${ }^{5}$ and \\ Corinna Kehrenberg ${ }^{6, *}$ \\ 1 Research Center for Emerging Infections and Zoonoses, University of Veterinary Medicine Hannover, \\ Foundation, 30559 Hannover, Germany; Veronika.Pilchova@tiho-hannover.de \\ 2 Lower Saxony State Office for Consumer Protection and Food Safety, 26203 Wardenburg, Germany; \\ Diana.Seinige@gmx.de \\ 3 Field Station for Epidemiology in Bakum, University of Veterinary Medicine Hannover, Foundation, \\ 30559 Hannover, Germany; Isabel.Hennig-Pauka@tiho-hannover.de \\ 4 Unit for Bioinformatics and Data Processing, Justus-Liebig-University Giessen, 35392 Giessen, Germany; \\ Kathrin.Buettner@vetmed.uni-giessen.de \\ 5 Institute of Food Quality and Food Safety, University of Veterinary Medicine Hannover, Foundation, \\ 30173 Hannover, Germany; Amir.Abdulmawjood@tiho-hannover.de \\ 6 Institute for Veterinary Food Science, Justus-Liebig-University Giessen, 35392 Giessen, Germany \\ * Correspondence: corinna.kehrenberg@vetmed.uni-giessen.de; Tel.: +49-641-9938250
}

check for

updates

Citation: Pilchová, V.; Seinige, D.; Hennig-Pauka, I.; Büttner, K.; Abdulmawjood, A.; Kehrenberg, C. Development and Validation of a Loop-Mediated Isothermal Amplification (LAMP) Assay for Rapid Detection of Glaesserella (Haemophilus) parasuis. Microorganisms 2021, 9, 41. https://dx.doi.org/ 10.3390/microorganisms 9010041

Received: 2 December 2020 Accepted: 21 December 2020 Published: 25 December 2020

Publisher's Note: MDPI stays neutral with regard to jurisdictional claims in published maps and institutional affiliations.

Copyright: () 2020 by the authors. Licensee MDPI, Basel, Switzerland. This article is an open access article distributed under the terms and conditions of the Creative Commons Attribution (CC BY) license (https: / / creativecommons.org/ licenses/by/4.0/).

\begin{abstract}
Glaesserella parasuis is a fastidious pathogen that colonizes the respiratory tract of pigs and can lead to considerable economic losses in pig production. Therefore, a rapid detection assay for the pathogen, preferably applicable in the field, is important. In the current study, we developed a new and improved detection method using loop-mediated isothermal amplification (LAMP). This assay, which targets the infB gene, was tested on a collection of 60 field isolates of G. parasuis comprising 14 different serovars. In addition, 63 isolates from seven different closely related species of the family Pasteurellaceae, including A. indolicus, A. porcinus, and A. minor, and a species frequently found in the respiratory tract of pigs were used for exclusivity experiments. This assay showed an analytical specificity of $100 \%$ (both inclusivity and exclusivity) and an analytical sensitivity of $10 \mathrm{fg} / \mu \mathrm{L}$. In further steps, 36 clinical samples were tested with the LAMP assay. An agreement of 77.1 (95\% CI: 59.9, 89.6) and 91.4\% (95\% CI: 75.9, 98.2) to the culture-based and PCR results was achieved. The mean limit of detection for the spiked bronchoalveolar lavage fluid was $2.58 \times 10^{2} \mathrm{CFU} / \mathrm{mL}$. A colorimetric assay with visual detection by the naked eye was tested to provide an alternative method in the field and showed the same sensitivity as the fluorescence-based LAMP assay. Overall, the optimized LAMP assay represents a fast and reliable method and is suitable for detecting $G$. parasuis in the laboratory environment or in the field.
\end{abstract}

Keywords: loop-mediated isothermal amplification (LAMP); Glaesserella parasuis; Haemophilus parasuis; pig; infB gene; rapid diagnostic; bronchoalveolar lavage fluid; BAL

\section{Introduction}

Glaesserella parasuis (G. parasuis), previously named Haemophilus parasuis, is a small pleomorphic gram-negative fastidious bacterium belonging to the family Pasteurellaceae [1]. The pathogen colonizes the upper respiratory tract of healthy pigs early on in life. However, infection of an animal with G. parasuis can have many different effects depending on the type of the strain, health status of the herd, age of the pig, simultaneous coinfections, animal welfare conditions, and many other factors [2,3]. Besides being a commensal, G. parasuis is also the etiological agent of Glässer's disease. This disease was described by 
Karl Glässer in 1906 and is characterized by polyserositis, arthritis, pericarditis, and serofibrinous inflammation of the pleura, which is often fatal [4]. It mainly affects weaners at the age of five or six weeks and specific pathogen-free (SPF) herds [5]. Acute or chronic progression of the disease mainly depends on the immunological status of the herd. In addition to Glässer's disease, G. parasuis can also be secondarily involved in lung infections, e.g., after viral infections, cause acute pneumonia without polyserositis [6], or can be responsible for acute septicemia [7]. Although G. parasuis is mainly associated with domestic pigs, its presence in the nasal cavity of wild boars has been confirmed as well [8,9]. Overall, the pathogen causes considerable economic losses in the swine industry every year due to the necessary antibiotic treatment, vaccinations, and deaths of animals.

So far, 15 serovars of $G$. parasuis have been defined, each differing in virulence $[10,11]$. In addition, a relatively high prevalence of non-typable (NT) strains has been described [12] Serovars $1,5,10,12,13$, and 14 are recognized as highly virulent, causing high morbidity or mortality in SPF pigs within four days [4]. On the American continent, primarily serovars 5 , 4, NT, 2, 12, 13, and 7 dominate in diseases [13,14], whereas in Europe, serovars 5, 4, 13, and NT [15,16] are dominant; in Asia, serovars 4, 5, 12, 13, NT, 14, and 2 are dominant [17-19].

G. parasuis is a commensal in the upper respiratory tract of pigs Amano, et al. [20]. Therefore, detection of the bacterium as a causative agent of Glässer's disease should always be done in the affected tissues or body fluids, e.g., in lung tissue, bronchoalveolar lavage fluid, and joint fluid. The classical culture-based method is currently still the gold standard for detection, although it is very time-consuming and not always successful in detecting the pathogen. In fact, G. parasuis ranks among delicate and fastidious organisms and, consequently, bacterial cultivation may lead to false-negative results. G. parasuis could also be detected with several serological tests, such as immunohistochemistry [21] or immunodiffusion [22], but these methods are usually unsuitable for broad screenings with high sample quantities. In addition, antibodies may not be produced at early stages of infections. Further "gold standards" for detecting G. parasuis are PCR-based methods, e.g., conventional PCR [23,24], serotype-specific PCR [17], multiplex PCR [25], or realtime PCR [26]. These provide high sensitivity and specificity, but generally require costly equipment and are therefore unsuitable to be used directly in the field.

In 2000, a method named loop-mediated isothermal amplification (LAMP) was developed [27]. In principle, four specially designed primers recognize six distinct loci of the target DNA sequence in this LAMP assay. The method amplifies DNA with very high specificity and efficiency under isothermal conditions. A great advantage of the method is also the rapidity as a target sequence can be amplified in an hour. In addition, the device for the LAMP analyses is small and portable and so it can be used on site at any time. LAMP has become widely popular for detecting pathogens in food and clinical samples [28-30], even including the detection of SARS-CoV-2, the etiological agent of COVID-19 [31].

For detecting G. parasuis, LAMP has already been used in the first approaches [32-34]. In these previous studies, different target genes were used, but to date, neither an optimized temperature nor suitable primer concentrations are available. In addition, these studies used water baths and visual detection methods, making standardized interpretation of the results more difficult.

The aim of the present study was therefore to establish and validate a new improved LAMP assay for detecting Glaesserella parasuis in cultures but also in field samples. The validation process had to include the testing of DNA from reference and field strains, DNA from closely related bacteria, and also native samples.

\section{Materials and Methods}

\subsection{Bacterial Strains}

For this study, G. parasuis field isolates ( $n=59$ ) were used, which were collected on pig farms from different geographical regions in Germany during the years 2011-2013 [35]. Unfortunately, the serotype was only available for 29 of the 50 field isolates. In addition, 
G. parasuis type strain DSM $21448^{\mathrm{T}}$ (Leibniz-Institute DSMZ, German Collection of Microorganisms and Cell Cultures $\mathrm{GmbH}$, Brunswick, Germany) served as a positive control in every experiment. As negative controls for the validation experiments, bacterial species genetically closely related (88-90\% identity of the target gene infB) to G. parasuis and frequently detected in the respiratory tract or infected joints of pigs were chosen. These strains included Actinobacillus minor CCUG 38923, Actinobacillus indolicus CCUG 39029, Actinobacillus porcinus CCUG 38924, and Actinobacillus arthritidis CCUG 24862 (all: Culture Collection University of Gothenburg (CCUG), Gothenburg, Sweden), as well as 11 Mannheimia haemolytica, 26 Actinobacillus pleuropneumoniae, 20 Pasteurella multocida, and two Bordetella bronchiseptica field isolates from the strain collection of the Institute for Veterinary Food Science, Justus-Liebig-University, Giessen, Germany. All G. parasuis isolates ( $n=60$ ) as well as all non-Glaesserella isolates $(n=62)$ tested in this study are listed in Table 1.

Table 1. Numbers, sources, and serovars of bacterial strains and isolates used for inclusivity and exclusivity tests in this study (G. parasuis and non-G. parasuis isolates).

\begin{tabular}{|c|c|c|c|}
\hline Species & $n$ & Serovars & Source/Reference \\
\hline $\begin{array}{c}\text { Glaesserella parasuis DSM } \\
21448^{\mathrm{T}} \\
\text { type strain }\end{array}$ & 1 & ND & $\begin{array}{l}\text { Leibniz-Institute } \\
\text { DSMZ }\end{array}$ \\
\hline $\begin{array}{l}\text { Glaesserella parasuis } \\
\text { field isolates }\end{array}$ & 29 & $1,2,3,4,5,6,8,9,10,11,12,13,14,15$ & \multirow{2}{*}{$\begin{array}{c}\text { IVD GmbH; } \\
\text { Institute collection } \\
{[35,36]}\end{array}$} \\
\hline $\begin{array}{l}\text { Glaesserella parasuis } \\
\text { field isolates }\end{array}$ & 30 & ND & \\
\hline $\begin{array}{c}\text { Actinobacillus minor CCUG } \\
38923^{\mathrm{T}} \\
\text { type strain }\end{array}$ & 1 & & $\begin{array}{l}\text { Culture Collection } \\
\text { University of } \\
\text { Gothenburg }\end{array}$ \\
\hline $\begin{array}{c}\text { Actinobacillus indolicus } \\
\text { CCUG } 39029^{\mathrm{T}} \\
\text { type strain }\end{array}$ & 1 & & $\begin{array}{l}\text { Culture Collection } \\
\text { University of } \\
\text { Gothenburg }\end{array}$ \\
\hline $\begin{array}{c}\text { Actinobacillus porcinus } \\
\text { CCUG } 38924^{\mathrm{T}} \\
\text { type strain }\end{array}$ & 1 & & $\begin{array}{l}\text { Culture Collection } \\
\text { University of } \\
\text { Gothenburg }\end{array}$ \\
\hline $\begin{array}{c}\text { Actinobacillus arthritis } \\
\text { CCUG } 24862^{\mathrm{T}} \\
\text { type strain }\end{array}$ & 1 & & $\begin{array}{l}\text { Culture Collection } \\
\text { University of } \\
\text { Gothenburg }\end{array}$ \\
\hline $\begin{array}{l}\text { Actinobacillus } \\
\text { pleuropneumoniae } \\
\text { field isolates }\end{array}$ & 26 & & Institute collection \\
\hline $\begin{array}{l}\text { Mannheimia haemolytica } \\
\text { field isolates }\end{array}$ & 11 & & Institute collection \\
\hline $\begin{array}{l}\text { Pasteurella multocida } \\
\text { field isolates }\end{array}$ & 20 & & Institute collection \\
\hline $\begin{array}{l}\text { Bordetella bronchiseptica } \\
\text { field isolates }\end{array}$ & 2 & & Institute collection \\
\hline
\end{tabular}

ND: not determined.

\subsection{Cultivation Conditions, Genomic DNA Isolation, and Species Confirmation}

All isolates were cultured on chocolate agar (Carl Roth $\mathrm{GmbH}$, Karlsruhe, Germany) supplemented with $10 \%$ defibrinated horse blood and were incubated at $35^{\circ} \mathrm{C}$ for 24 to $48 \mathrm{~h}$ [36]. Genomic DNA of the bacterial strains and isolates was extracted with a Qiagen DNeasy Blood \& Tissue Kit (Qiagen GmbH, Hilden, Germany) in accordance with the manufacturer's instructions. Briefly, five to ten colonies of bacteria were harvested from agar plates with an inoculation loop and suspended into a mixture of $180 \mu \mathrm{L}$ Buffer ATL, 
a tissue lysis buffer, and $20 \mu \mathrm{L}$ Proteinase $\mathrm{K}$. The lysis step was performed in a shaking heat block at $56{ }^{\circ} \mathrm{C}$ for $1.5 \mathrm{~h}$. Subsequently, $200 \mu \mathrm{L}$ Buffer AL and $200 \mu \mathrm{L} 99.8 \%$ ethanol were added. After each step, the mixture was properly vortexed to improve the lysis process. The content of the tube was transferred into a DNeasy Mini spin column. Series of two washing steps with $500 \mu \mathrm{L}$ of washing buffers were performed, followed by centrifugation steps $(60 \mathrm{~s}, 6100 \times g)$. Finally, $100 \mu \mathrm{L}$ Buffer AE was added as the final elution volume. For comparison, a rapid method was used in parallel for each clinical swab sample and DNA heat extraction was performed. For heat extraction, a volume of $100 \mu \mathrm{L}$ of the transport medium was placed in a shaking heat block at $99{ }^{\circ} \mathrm{C}$ for $10 \mathrm{~min}$ at $400 \mathrm{rpm}$. Subsequently, the samples were centrifuged at $20,817 \times g$ for $5 \mathrm{~min}$ and the supernatant was transferred to a new $1.5 \mathrm{~mL}$ tube for further analysis. The results of both extraction methods were compared. To determine whether inhibition factors play a role in the LAMP assay, both undiluted and diluted DNA samples (1:10 in Buffer AE) were tested.

For species confirmation of G. parasuis isolates, a PCR assay targeting the 16S rRNA gene was performed, amplifying an $821 \mathrm{bp}$ region as described earlier [24].

\subsection{Native Samples and Culture-Based Detection of G. parasuis}

For the investigation of clinical field samples, 36 swabs (MSwab ${ }^{\circledR}$ Mast Group Ltd., Reinfeld, Germany) from different organs (pericardium, tonsils, bronchi, joints, serous membranes, and brain) were collected from August 2018 until September 2019 and were provided by the Field Station for Epidemiology in Bakum, University of Veterinary Medicine Hannover, Foundation, Germany. First, all samples were microbiologically examined there using routine diagnostic methods [37]. For this purpose, organs or swabs of the respective organs were streaked on Gassner agar (Oxoid Ltd., Hampshire, UK), Columbia Blood agar (Becton Dickinson, Heidelberg, Germany), Columbia CNA (colistin-nalidixic acid) agar (Becton Dickinson), and chocolate blood agar plates containing adenine dinucleotide (blood agar No. 2, Becton Dickinson). Gassner agar, Columbia blood agar and CNA agar plates were incubated aerobically for $16 \mathrm{~h}$ at $36 \pm 1{ }^{\circ} \mathrm{C}$. Chocolate agar plates were incubated under microaerophilic conditions with $8-10 \% \mathrm{CO}_{2}$ for $16 \mathrm{~h}$ at $36 \pm 1{ }^{\circ} \mathrm{C}$. Colonies showing a colony morphology suspicious of G. parasuis were then subjected to biochemical tests (catalase, urease), tests for satellite phenomenon with Staphylococcus aureus, as well as $\mathrm{X}$ - and V-factor-dependent growth.

In addition, 36 tissue swab samples were transported in $1 \mathrm{~mL}$ Amies transport medium to the laboratory for LAMP analysis. There, DNA was extracted as described above.

\subsection{Development of the LAMP Assay}

\subsubsection{Target Gene and Primer Design}

For the development of the LAMP assay, two different target genes, 16S rDNA and inf $B$, which were described as suitable targets in previous studies [23,26], were taken into consideration. Three distinct primer sets, each consisting of six primers, were designed. For detecting the $16 \mathrm{~S}$ ribosomal RNA gene, a $1477 \mathrm{bp}$ nucleotide sequence deposited in the GenBank of the National Center for Biotechnology (NCBI), Bethesda, MD, USA (accession number AB078973.1), was used as target sequence. The primer set was developed by using the PrimerExplorer V4 software (Eiken Chemical Co. Ltd., Tokyo, Japan). The LAMP Designer (PREMIER Biosoft International ver. 1.15, Palo Alto, CA, USA) and Primer Explorer V4 software were also used to design two primer sets targeting the infB gene. The nucleotide sequence of the infB gene (1360 bp) was available from the National Center for Biotechnology (NCBI) GenBank (Bethesda MD, USA) under accession number DQ410886. All the initially used primers are shown in supplementary Table S1.

By using the Basic Local Alignment Search Tool (BLAST) (https://blast.ncbi.nlm. nih.gov/Blast.cgi), the target sequences were compared to sequences of other bacterial species in the databases. The sequences from the species with the highest identity at the nucleotide sequence level (Actinobacillus minor, accession number EF055562.1, 90\% identity; Actinobacillus indolicus, EF059971.1, 89\% identity; Actinobacillus porcinus, EF059970.1, 
88\% identity; Actinobacillus porcitonsillarum, EF055563.1, 88\% identity) were selected and matched with the sequence of the infB gene from G. parasuis. In this way, the species-specific nucleotide regions of $G$. parasuis were identified and their location was used for the final selection of the primer set. The chosen primer set (Table 2) was synthesized by Eurofins Genomics (Eurofins Genomics GmbH, Ebersberg, Germany) and consisted of six individual primers-two inner primers, two outer primers, and two loop primers (Figure 1). The forward inner primer (FIP) consisted of the F1c and F2 sequences, the backward inner primer (BIP)—of the B1c and B2 sequences. F3 and B3 primers represented the outer primers.

Table 2. Most suitable primer set used for the LAMP assay targeting the infB gene.

\begin{tabular}{|c|c|c|c|}
\hline Primer & Sequence & $\begin{array}{l}\text { Positions in infB } \\
\text { (Accession No. } \\
\text { DQ410886) }\end{array}$ & $\begin{array}{c}\text { Length } \\
\text { (bp) }\end{array}$ \\
\hline F3 & GCGTGAAGTGGCGTTAT & 739 & 17 \\
\hline B3 & GATAATGCGACGTGCTGA & 1063 & 18 \\
\hline $\mathrm{FIP}(\mathrm{F} 1 \mathrm{c}+\mathrm{F} 2)$ & $\begin{array}{l}\text { CAATCGCTTCTACAGAGCCTTGT- } \\
\text { TTAGCAATATGGCGGAAGG }\end{array}$ & 902,822 & 23,19 \\
\hline $\mathrm{BIP}(\mathrm{B} 1 \mathrm{c}+\mathrm{B} 2)$ & $\begin{array}{l}\text { GCTCTGGCGTAGGTGGTATTAC- } \\
\text { AAGGCAAGTACAATAGCGTT }\end{array}$ & 954,1026 & 22,20 \\
\hline Loop F & TCACAATCACGTTCAATTCTGC & 869 & 22 \\
\hline Loop B & AACCTTAGCGGCAGCG & 988 & 16 \\
\hline
\end{tabular}

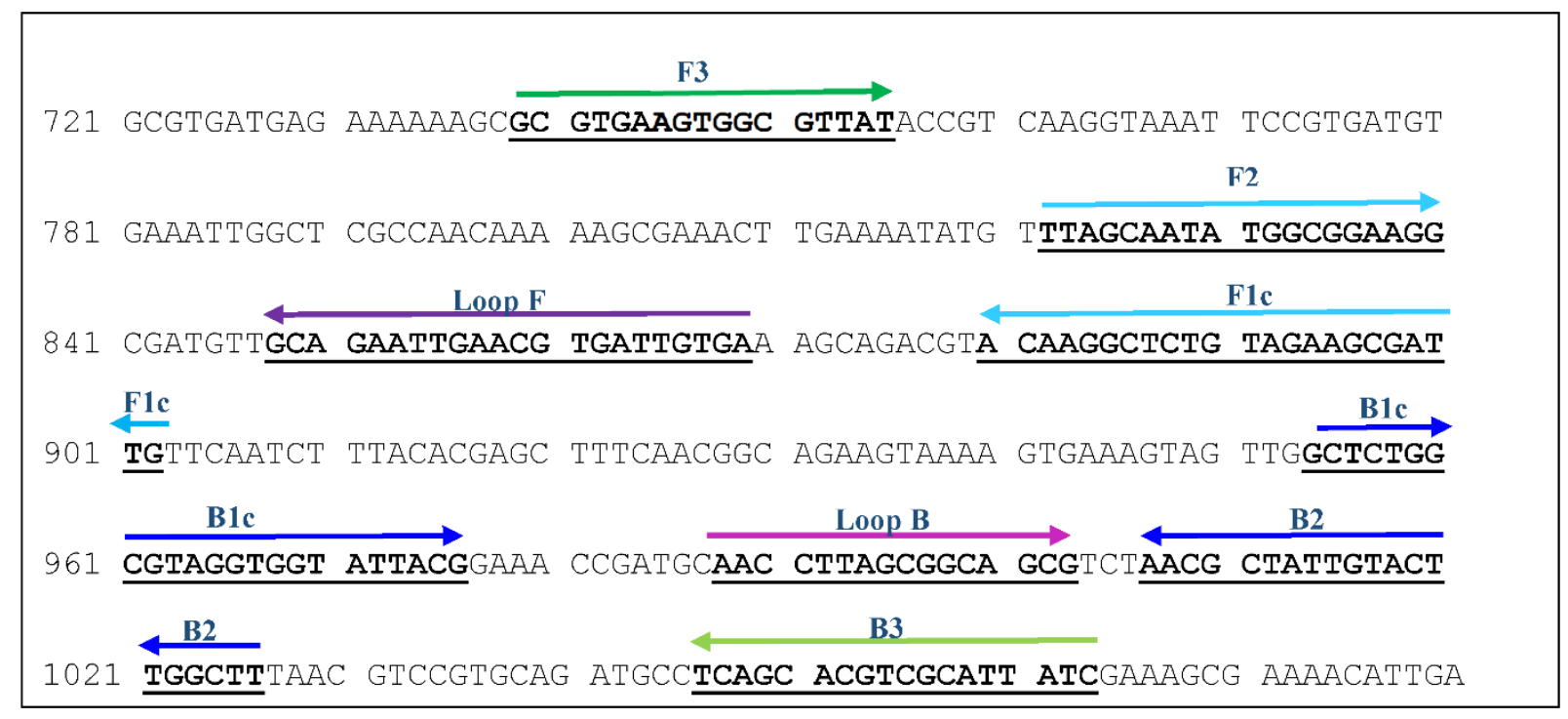

Figure 1. Nucleotide sequence of the infB gene (accession no. DQ410886) with binding positions of the LAMP primers.

Since it was shown in previous studies that increasing the primer concentrations of FIP, BIP, loop F, and loop B (not F3 and B3) accelerates the amplification process [38], the primers were used in different concentrations (Table 3). 
Table 3. Different concentrations of the primer mix used.

\begin{tabular}{ccc}
\hline Primers & $\begin{array}{c}\text { Standard Concentration of } \\
\text { the Primer Mix }\end{array}$ & Concentrated Primer Mix \\
\hline F3, B3 & $0.2 \mu \mathrm{M}$ & $0.2 \mu \mathrm{M}$ \\
\hline FIP, BIP & $0.8 \mu \mathrm{M}$ & $2 \mu \mathrm{M}$ \\
\hline Loop F, loop B & $0.4 \mu \mathrm{M}$ & $1 \mu \mathrm{M}$ \\
\hline
\end{tabular}

\subsubsection{LAMP Reaction Mixture and Amplification}

Each tube with a total of $25 \mu \mathrm{L}$ reaction mixture contained $15 \mu \mathrm{L}$ Isothermal Master Mix ISO-001 (OptiGene Limited, Horsham, UK), $2.5 \mu \mathrm{L}$ primer mix, $2.5 \mu \mathrm{L}$ nuclease-free water, and $5 \mu \mathrm{L}$ DNA template. The master mix included DNA polymerase, thermostable inorganic pyrophosphatase, reaction buffer, $\mathrm{MgSO}_{4}$, deoxyribonucleotide triphosphates (dNTPs), and double-stranded DNA (ds-DNA) binding dye. A mixture made of master mix, primer mix, and nuclease-free water served as the no template control in each run. The DNA concentrations of all positive and negative controls were quantified with the Nanodrop 2000c (Thermo Fisher Scientific Inc., Waltham, MA, USA) and subsequently adjusted to $0.1 \mathrm{ng} / \mu \mathrm{L}$. For amplification, a Genie II ${ }^{\circledR}$ (OptiGene Limited, Horsham, UK) instrument was used along with Genie ${ }^{\circledR}$ strips-proprietary 8-microtube strips. Genie II ${ }^{\circledR}$ is a portable device consisting of two separate heating blocks, each for one strip, and a TFT /LCD display (thin film transistor/ liquid crystal display) to observe the reaction in real time. All data from the Genie ${ }^{\circledR}$ II device were processed in the software program Genie Explorer available at http:/ /www.optigene.co.uk/support/. After preparing the reaction mixture, the solution was pipetted into tubes and incubated under isothermal conditions. At the end of the amplification, a melting step was performed beginning at $98^{\circ} \mathrm{C}$ and decreasing $1{ }^{\circ} \mathrm{C}$ per minute to an end point of $80^{\circ} \mathrm{C}$. Results were evaluated in the Genie Explorer program as represented characteristically in Figure 2. Optimization of the reaction temperature was performed with a temperature gradient on a series of seven identical DNA samples from positive control strain G. (H.) parasuis DSM 21448 concentrated at $0.1 \mathrm{ng} / \mu \mathrm{L}$. The temperature gradient ranged from $63^{\circ} \mathrm{C}$ to $69^{\circ} \mathrm{C}$ in steps of $1{ }^{\circ} \mathrm{C}$.

\subsection{Alternative LAMP Assay with Colorimetric Detection and Gel Electrophoresis}

In addition, an alternative LAMP assay with visual amplicon detection based on a color change was tested. The isothermal OptiGene Isothermal Master Mix was replaced by the colorimetric WarmStart LAMP 2X Master Mix (New England BioLabs, Frankfurt am Main, Germany). This Master Mix contains a pH indicator, phenol red, in a low-buffer reaction solution, which causes a color change from pink to yellow depending on the amplification process. This assay was tested to provide an alternative for a field application as given by visualization of the process with the naked eye. This can speed up and simplify the screening process in the field. The same serial dilution steps used in the Genie II ${ }^{\circledR}$ amplifications (analytical sensitivity test) were placed in a heating block at $66^{\circ} \mathrm{C}$ for $45 \mathrm{~min}$ when using this alternative assay (Figure 3). To confirm the reaction of the colorimetric master mix, detection of the LAMP amplicons was performed by gel electrophoresis. An amount of $6 \mu \mathrm{L}$ of the amplified product (ten-fold serial dilution from $10 \mathrm{ng} / \mu \mathrm{L}$ to $1 \mathrm{fg} / \mu \mathrm{L}$ ) and a $1 \mathrm{~kb}$ Plus DNA ladder (Thermo Fisher Scientific) were transferred onto a $2 \%$ agarose gel with a running time of $90 \mathrm{~min}$ at $200 \mathrm{~V}$. The final product was stained with ethidium bromide and was subsequently made visible under UV light. 


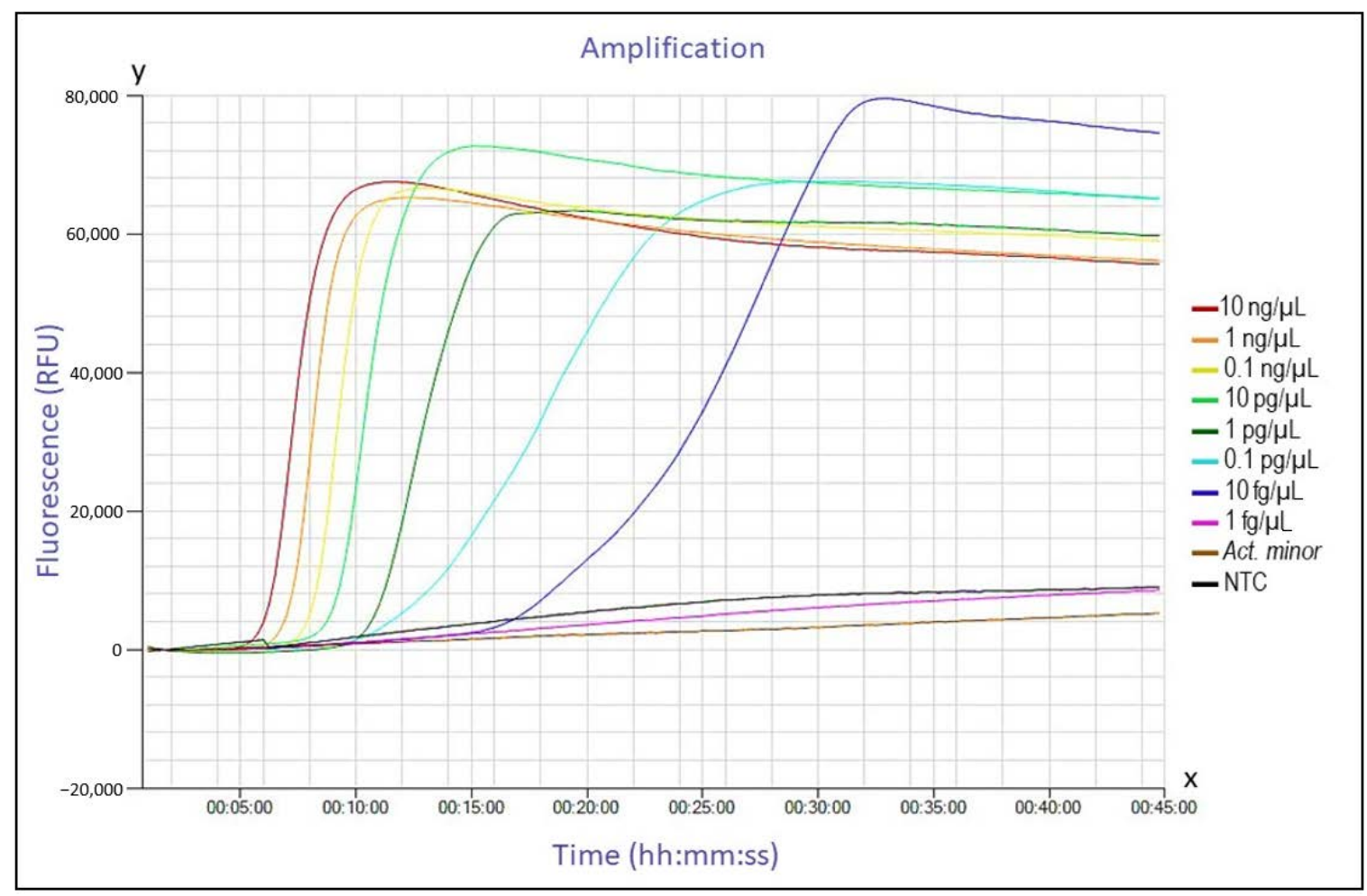

Figure 2. Example of a typical LAMP run in Genie ${ }^{\circledR}$ II. The graph was created in the program Genie Explorer and shows an analytical sensitivity test using the concentrated master mix. The x-axis shows the amplification time (hh:mm:ss), while the $\mathrm{y}$-axis shows the fluorescence expressed in relative fluorescence units (RFU). Red, orange, yellow, green, dark green, blue, dark blue, and pink are the colors used to represent ten-fold serial dilutions of G. (H.) parasuis (DSM 21448) genomic DNA from $10 \mathrm{ng} / \mu \mathrm{L}$ to $1 \mathrm{fg} / \mu \mathrm{L}$, respectively. The brown curve represents DNA from Actinobacillus minor strain CCUG $38923^{\mathrm{T}}$ $(0.1 \mathrm{ng} / \mu \mathrm{L})$ and the black curve represents the no template control (NTC).

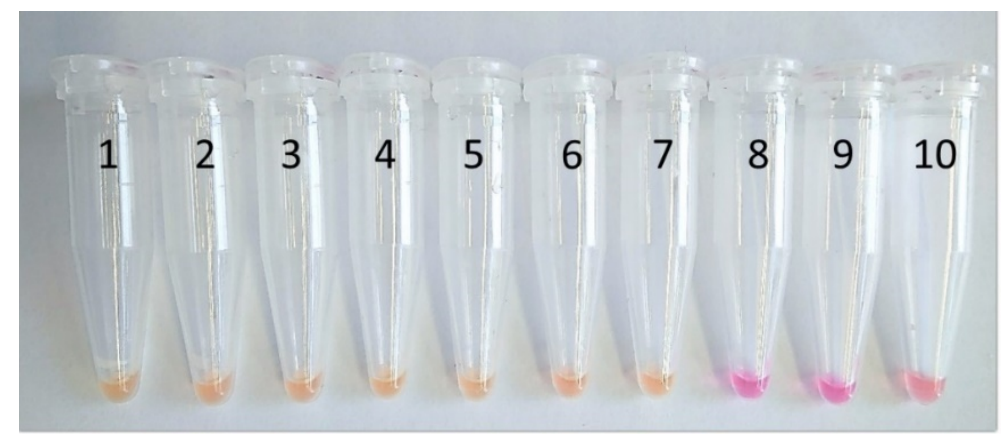

Figure 3. Results of the WarmStart Colorimetric LAMP 2X Master Mix assay for detection of LAMP amplicons with the naked eye. Samples 1-8: serial dilutions of DNA from strain G. (H.) parasuis DSM 21448 starting at concentrations of $10 \mathrm{ng} / \mu \mathrm{L}$ up to $1 \mathrm{fg} / \mu \mathrm{L}$. Sample 9: DNA from Actinobacillus minor CCUG 38923 ${ }^{\mathrm{T}}$. Sample 10: no template control.

\subsection{Analytical Sensitivity of the LAMP Assay}

The analytical sensitivity was evaluated based on a ten-fold serial dilution of nucleic acid extracts from the reference strain G. parasuis DSM $21448^{\mathrm{T}}$ in TE (Tris EDTA) buffer. The test concentrations ranged between $10 \mathrm{ng} / \mu \mathrm{L}$ and $1 \mathrm{fg} / \mu \mathrm{L}$. Two primer concentration variants-standard and concentrated-were tested (Table 4). Three independent experiments were performed. 
Table 4. Comparison of detection times using the standard and concentrated primer mixtures in a serial dilution $(1 \mathrm{ng} / \mu \mathrm{L}-$ $1 \mathrm{fg} / \mu \mathrm{L})$ of DNA of the reference strain G. (H.) parasuis DSM $21448^{\mathrm{T}}(n=3)$.

\begin{tabular}{|c|c|c|c|c|c|c|c|c|c|}
\hline c (std. PM) & $10 \mathrm{ng} / \mu \mathrm{L}$ & $1 \mathrm{ng} / \mu \mathrm{L}$ & $0.1 \mathrm{ng} / \mu \mathrm{L}$ & $10 \mathrm{pg} / \mu \mathrm{L}$ & $1 \mathrm{pg} / \mu \mathrm{L}$ & $0.1 \mathrm{pg} / \mu \mathrm{L}$ & $10 \mathrm{fg} / \mu \mathrm{L}$ & $1 \mathrm{fg} / \mu \mathrm{L}$ & NTC \\
\hline $\begin{array}{c}\text { M Dt } \\
(\mathrm{mm}: \mathrm{ss})\end{array}$ & $10: 25$ & $11: 30$ & $12: 55$ & $14: 40$ & $16: 55$ & $19: 50$ & - & - & - \\
\hline $\begin{array}{c}\text { SD Dt } \\
(\mathrm{mm}: \mathrm{ss})\end{array}$ & 00:09 & $00: 26$ & $00: 43$ & $00: 57$ & $00: 57$ & 02:51 & - & - & - \\
\hline M At $\left({ }^{\circ} \mathrm{C}\right)$ & 85.83 & 85.83 & 85.97 & 85.93 & 85.90 & 85.97 & - & - & - \\
\hline $\begin{array}{c}\text { c (conc. } \\
\text { PM) }\end{array}$ & $10 \mathrm{ng} / \mu \mathrm{L}$ & $1 \mathrm{ng} / \mu \mathrm{L}$ & $0.1 \mathrm{ng} / \mu \mathrm{L}$ & $10 \mathrm{pg} / \mu \mathrm{L}$ & $1 \mathrm{pg} / \mu \mathrm{L}$ & $0.1 \mathrm{pg} / \mu \mathrm{L}$ & $10 \mathrm{fg} / \mu \mathrm{L}$ & $1 \mathrm{fg} / \mu \mathrm{L}$ & NTC \\
\hline $\begin{array}{c}\text { M Dt } \\
(\mathrm{mm}: \mathrm{ss})\end{array}$ & $06: 50$ & $07: 50$ & 08:50 & $10: 05$ & $12: 05$ & $16: 25$ & $27: 50$ & - & - \\
\hline $\begin{array}{l}\text { SD Dt } \\
\text { (mm:ss) }\end{array}$ & 00:09 & 00:09 & 00:09 & 00:09 & 00:09 & 01:40 & $11: 25$ & - & - \\
\hline M At $\left({ }^{\circ} \mathrm{C}\right)$ & 85.47 & 85.47 & 85.53 & 85.57 & 85.47 & 85.50 & 85.60 & - & - \\
\hline
\end{tabular}

$\mathrm{c}=$ DNA concentration; std. $\mathrm{PM}=$ primer mix with standard primer concentration; conc. $\mathrm{PM}=$ concentrated primer mix; $\mathrm{M}=$ mean of all amplification times and annealing temperatures $(n=3) ; \mathrm{SD}=$ standard deviation; $\mathrm{Dt}=$ detection time; At $=$ annealing temperature (melting temperature); NTC $=$ no template control; $-=$ no positive signal.

\subsection{Analytical Specificity of the LAMP Assay}

The concept of analytical specificity is often described by inclusivity defined according to the Association of Official Analytical Chemists (AOAC) as "strains or isolates or variants of the target agent that the method can detect" (selectivity) and exclusivity-"strains or isolates or variants of the target agent that the method must not detect" (cross-reactivity) [39]. A total of 43 strains of Glaesserella parasuis with 14 different serotypes were used for inclusivity testing [35]. A total of 29 Actinobacillus spp. isolates, 11 Mannheimia haemolytica isolates, 20 Pastereulla multocida isolates, and 2 Bordetella bronchiseptica isolates were used for the tests of exclusivity (the isolates used are shown in Table 1).

\subsection{Determination of the Limit of Detection}

To investigate the limit of detection, a suspension of G. parasuis DSM $21448^{\mathrm{T}}$ in Müller-Hinton II bouillon enriched with chicken serum and NADH (nicotinamide adenine dinucleotide, reduced form) [35] was placed in a shaking incubator at $35^{\circ} \mathrm{C}$ for $18 \mathrm{~h}$. After incubation, a ten-fold serial dilution ranging from $10^{8}$ to $1 \mathrm{CFU} / \mathrm{mL}$ was prepared in $0.9 \%$ $\mathrm{NaCl}$ by using a densitometer (starting at McFarland 0.5, measured with a densitometer, BioMérieux Marcy-l'Étoile, France). On each dilution step, a volume of $1 \mathrm{~mL}$ was used for DNA isolation with QIAGEN GmbH DNeasy Blood \& Tissue Kit and was subsequently tested with the LAMP assay. For microbiological cell counts, a volume of $100 \mu \mathrm{L}$ from each dilution step was spread on a chocolate agar plate with a hockey stick, followed by incubation at $35^{\circ} \mathrm{C}$ for $24 \mathrm{~h}$. Bacterial colonies were counted on chocolate agar plates (10 to 150 colonies) and the results were expressed in CFU $/ \mathrm{mL}$.

\subsection{Investigation of Spiked Bronchoalveolar Lavage Fluid}

For the LAMP assay validation, spiking experiments were performed under simulated conditions. As a suitable spiking matrix, bronchoalveolar lavage (BAL) fluid was taken from healthy pigs provided by the Field Station for Epidemiology in Bakum, Germany. To prove the absence of G. parasuis in the bronchoalveolar lavage fluid, samples were tested with the LAMP assay as well as with a conventional PCR assay, which was proved to be well suited in a previous study [24]. Moreover, a poly 16S rRNA gene PCR was performed to verify the presence of a bacterial DNA background. Furthermore, to determine the limit of detection in these samples, a ten-fold serial dilution of G. parasuis cells in $0.9 \% \mathrm{NaCl}$ starting at $10^{8}$ (McFarland 0.5) up to $10^{1} \mathrm{CFU} / \mathrm{mL}$ was prepared as previously described. On each dilution step, $100 \mu \mathrm{L}$ were spiked into $900 \mu \mathrm{L}$ of the BAL fluid, while another 
$100 \mu \mathrm{L}$ were spread on chocolate agar and incubated at $35^{\circ} \mathrm{C}$ for $24 \mathrm{~h}$ to estimate the $\mathrm{CFU} / \mathrm{mL}$ as described above. A volume of $100 \mu \mathrm{L}$ from the spiked BAL was then diluted in $900 \mu \mathrm{L} \mathrm{NaCl}$ and centrifuged and the pellet was used for DNA isolation with a Qiagen Blood \& Tissue kit. Five independent experiments were performed.

The agreement between the methods was calculated as a percentage of equal results, with upper and lower binomial confidence intervals calculated in accordance with the Clopper-Pearson method [40].

\section{Results}

\subsection{Assay Optimisation}

Two different target genes, $16 \mathrm{~S}$ rDNA and infB, were compared in this study. The primer set targeting the $16 \mathrm{~S}$ ribosomal RNA gene showed cross-reaction (positive amplification results in the LAMP assay) with Mannheimia haemolytica isolates and was therefore excluded from the further course of this study (data not shown). One primer set targeting the infB gene, which was designed with the software Primer Explorer, showed cross-reaction with Actinobacillus minor strain CCUG $38923^{\mathrm{T}}$ and was therefore excluded as well. However, the second primer set (designed by LAMP design) targeting the infB gene resulted in positive amplifications for all tested G. parasuis isolates, but not for the other closely related bacterial strains and isolates included in the study. Due to its ability to differentiate between the bacterial species, this primer set was used for all further experiments. In addition, a temperature gradient was tested between 63 and $69{ }^{\circ} \mathrm{C}$ and the fastest amplification time was achieved with $66^{\circ} \mathrm{C}(08: 55 \mathrm{~min}$ at a DNA concentration of $0.1 \mathrm{ng} / \mu \mathrm{L})$.

\subsection{Analytical Sensitivity}

Runs $(n=3)$ with concentrated primers in the master mix (for concentrations see Table 3) showed a detection limit of $10 \mathrm{fg} / \mu \mathrm{L}$ DNA with a mean detection time between 6:50 and 27:50 min (Table 4). In contrast, when using the standard concentrated primer mix, one order of magnitude was lost in the determination of the detection limit, and the lowest concentration that still led to amplification of the targets was $0.1 \mathrm{pg} / \mu \mathrm{L}$ DNA of the test strain with mean detection times between 10:25 and 19:15 min (Table 4). An example of an analytical sensitivity run in the Genie Explorer program is presented in Figure 2.

In addition, an assay based on a colorimetric detection reaction was tested. The detection of a color change with the naked eye using a colorimetric master mix and amplification in the heating block resulted in a detection limit of $10 \mathrm{fg} / \mu \mathrm{L}$, which is the same result as obtained with the Genie ${ }^{\circledR}$ II assay (Figure 3). Even with the colorimetric detection, all negative controls remained visibly negative (shown in pink (samples 8-10)), while the positive samples turned dark yellow (samples 1-7). Gel electrophoresis confirmed results of the colorimetric test and showed a typical band pattern starting at the detection limit of $10 \mathrm{fg} / \mu \mathrm{L}$ DNA and for higher DNA concentrations (Figure 4).

Based on these results, a LAMP protocol with a temperature of $66^{\circ} \mathrm{C}$, a running time of $45 \mathrm{~min}$, and the concentrated primers in the master mix was created and used for all further experiments.

\subsection{Analytical Specificity}

When using the optimized protocol, no cross-reactivity with any other Pasteurellaceae species (Actinobacillus minor, Actinobacillus indolicus, Actinobacillus porcinus, Actinobacillus arthritis, Actinobacillus pleuropneumoniae, Mannheimia haemolytica, Pasteurella multocida) or non-related species (Bordetella bronchiseptica) was observed, while all G. parasuis isolates showed a positive result. This corresponded to the inclusivity and exclusivity of $100 \%$. According to the manufacturer of Genie ${ }^{\circledR}$ II devices, a positive result is defined as the occurrence of an amplification product in combination with a peak in the melting curve (also designated by the manufacturer as annealing temperature) at the expected temperature. A melting temperature of $85.3 \pm 0.6{ }^{\circ} \mathrm{C}$ was determined during the inclusivity tests. 


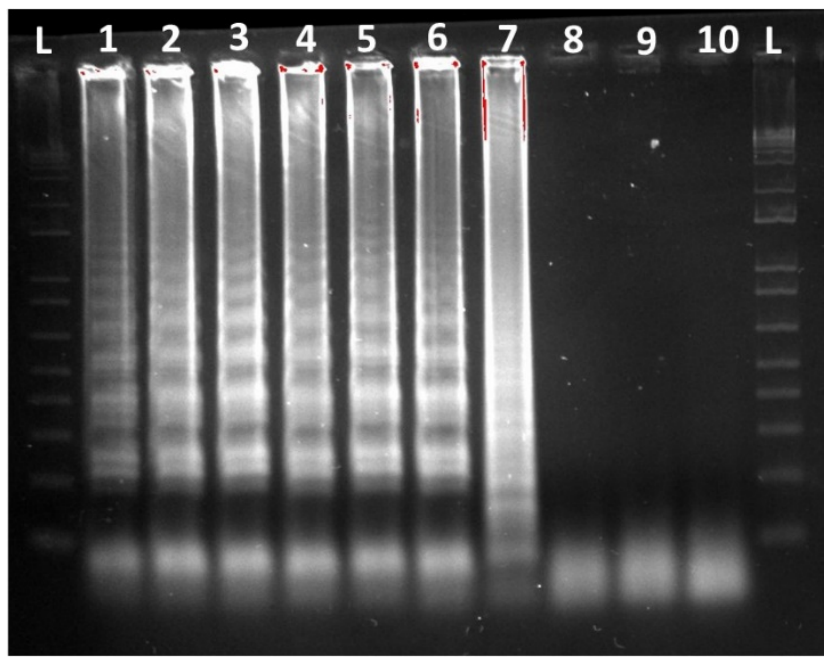

Figure 4. Analysis of the LAMP amplification products using gel electrophoresis. L lanes: $1 \mathrm{~kb}$ Plus DNA ladder. Lanes 1-8: amplification products from strain G. (H.) parasuis DSM 21448 starting at concentrations of $10 \mathrm{ng} / \mu \mathrm{L}$ up to $1 \mathrm{fg} / \mu \mathrm{L}$. Lane 9: DNA from Actinobacillus minor CCUG $38923^{\mathrm{T}}$. Lane 10: no template control.

\subsection{Detection of G. parasuis in Spiked Bronchoalveolar Lavage Fluids and Limit of Detection}

To demonstrate the suitability of the method for clinical samples, spiked BAL fluids, which had been previously identified as G. parasuis-free, were used. These samples all showed a bacterial background flora as determined by a poly $16 \mathrm{~S}$ rDNA PCR assay [41]. In addition, spiked $0.9 \% \mathrm{NaCl}$ samples were used. This enabled a comparison of two different matrices, which also differed in the presence and absence of a bacterial background flora. However, the CFU-based detection limit determined by two-fold serial dilution series of spiked $\mathrm{NaCl}$ samples was $3.5 \times 10^{2}$ G. parasuis cells per $\mathrm{mL} \mathrm{NaCl}$, while spiked BAL fluids showed a mean detection limit of $2.58 \times 10^{2} \mathrm{G}$. parasuis cells per $\mathrm{mL}$ (ranged between $2.1 \times 10^{2}$ to $2.1 \times 10^{3}$ cells $/ \mathrm{mL}$ ).

\subsection{Detection of G. parasuis in Clinical Field Samples}

Out of 36 organ swab samples, 11 were positive in the non-quantitative culturebased detection of G. parasuis (corresponding to a percentage of $30.6 \%$ ), while $15(41.6 \%$ ) yielded positive results in the LAMP assay when undiluted DNA from the isolation kit was used (Table 5). This corresponded to a $77.1 \%$ agreement (95\% confidence interval (CI): 59.9, 89.6) between the methods (Table 6). Using the conventional PCR assay as described earlier [24], 12 samples (33.3\%) were PCR-positive. Thus, 91.4\% (95\% CI: 76.9, 98.2) and 85.7\% (95\% CI: 69.7, 95.2) of the PCR results were in agreement with the results of the LAMP with undiluted kit-extracted DNA or the results of the conventional PCR, respectively. In total, five of the samples tested negative with the culture-based method were positive in the LAMP assay, and in three of the cases, the LAMP result was confirmed by conventional PCR. In contrast, G. parasuis was detected in two swabs only by conventional microbiological examination. When comparing the two DNA extraction methods (kit and heat extraction, each with undiluted DNA; Table 5), the results only differed for two samples (swabs from the pericardium). Furthermore, genomic DNA was tested undiluted and diluted 1:10 to observe whether such an adjustment affected amplification. In the case of isolation with the kit, two samples gave a negative result after dilution compared to the undiluted samples, whereas dilution of DNA after heat extraction in most cases led only to faster detection times (Table 6). 
Table 5. Results of 36 swab samples from different organs of pigs tested with the LAMP assay and a conventional PCR assay including a comparison of two different DNA extraction methods and diluted versus undiluted samples.

\begin{tabular}{|c|c|c|c|c|c|c|c|c|}
\hline \multirow[b]{3}{*}{ No. } & \multirow[b]{3}{*}{ Organ } & \multirow[b]{3}{*}{ MI } & \multicolumn{2}{|c|}{ DNA Isolation with KIT } & \multicolumn{2}{|c|}{ HEAT-Extracted DNA } & \multirow{2}{*}{\multicolumn{2}{|c|}{$\begin{array}{c}\text { Results } \\
\text { Summarized }\end{array}$}} \\
\hline & & & \multirow{2}{*}{$\begin{array}{l}\text { Undiluted } \\
\text { Dt (mm:ss) }\end{array}$} & \multirow{2}{*}{$\begin{array}{l}\text { Diluted 1:10 } \\
\text { Dt (mm:ss) }\end{array}$} & \multirow{2}{*}{$\begin{array}{l}\text { Undiluted } \\
\text { Dt (mm:ss) }\end{array}$} & \multirow{2}{*}{$\begin{array}{c}\text { Diluted 1:10 } \\
\text { Dt (mm:ss) }\end{array}$} & & \\
\hline & & & & & & & LAMP & PCR \\
\hline 1 & pericardium & - & - & - & - & - & - & - \\
\hline 2 & tonsils & - & - & - & - & - & - & - \\
\hline 3 & tonsils & - & - & - & - & - & - & - \\
\hline 4 & tonsils & - & - & - & - & - & - & - \\
\hline 5 & tonsils & - & - & - & - & - & - & - \\
\hline 6 & pericardium & - & $23: 15$ & - & - & - & $+/-$ & - \\
\hline 7 & pericardium & - & $27: 00$ & - & $38: 00$ & $28: 15$ & + & + \\
\hline 8 & pericardium & - & - & - & - & - & - & - \\
\hline 9 & pericardium & - & - & - & - & - & - & - \\
\hline 10 & pericardium & - & - & - & - & - & - & - \\
\hline 11 & pericardium & - & $13: 15$ & $12: 15$ & $42: 45$ & $27: 15$ & + & + \\
\hline 12 & bronchi & + & $14: 30$ & $15: 15$ & $35: 45$ & $13: 30$ & + & + \\
\hline 13 & bronchi & + & $18: 15$ & $12: 30$ & $41: 30$ & $16: 45$ & + & + \\
\hline 14 & bronchi & + & $13: 30$ & $13: 15$ & $35: 45$ & $12: 15$ & + & + \\
\hline 15 & bronchi & + & $18: 15$ & - & $19: 45$ & $20: 45$ & + & + \\
\hline 16 & joint & + & $14: 15$ & $10: 45$ & $41: 45$ & $23: 00$ & + & + \\
\hline 17 & $\begin{array}{c}\text { serous } \\
\text { membrane }\end{array}$ & - & $14: 15$ & $14: 30$ & $44: 00$ & $28: 00$ & + & + \\
\hline 18 & brain & - & - & - & - & - & - & - \\
\hline 19 & pericardium & + & $19: 45$ & $14: 00$ & $24: 45$ & $14: 45$ & + & + \\
\hline 21 & bronchi & + & - & - & - & - & - & - \\
\hline 22 & $\begin{array}{c}\text { serous } \\
\text { membrane }\end{array}$ & + & $11: 00$ & $12: 00$ & $13: 00$ & $14: 30$ & + & + \\
\hline 23 & lung & + & - & - & - & - & - & - \\
\hline 24 & pericardium & + & $11: 30$ & $12: 45$ & $21: 15$ & $27: 30$ & + & + \\
\hline 25 & pericardium & + & $14: 00$ & $15: 45$ & - & - & $+/-$ & + \\
\hline 26 & pericardium & - & - & ND & ND & ND & - & - \\
\hline 27 & bronchi & - & - & ND & ND & ND & - & - \\
\hline 28 & $\begin{array}{c}\text { serous } \\
\text { membrane }\end{array}$ & - & - & ND & ND & ND & - & - \\
\hline 29 & pericardium & - & - & ND & ND & ND & - & - \\
\hline 30 & pericardium & - & - & ND & ND & ND & - & - \\
\hline 31 & pericardium & - & $18: 15$ & ND & ND & ND & - & - \\
\hline 32 & pericardium & - & - & ND & ND & ND & - & - \\
\hline 33 & $\begin{array}{c}\text { serous } \\
\text { membrane }\end{array}$ & - & - & ND & ND & ND & - & - \\
\hline 34 & pericardium & - & $38: 15$ & ND & ND & ND & - & - \\
\hline 35 & pericardium & - & - & ND & ND & ND & - & - \\
\hline 36 & pericardium & - & - & ND & ND & ND & - & - \\
\hline
\end{tabular}

$\mathrm{SD}( \pm)$ = standard deviation; $\mathrm{Dt}=$ detection time; $\mathrm{MI}=$ culture-based investigation; $\mathrm{ND}=$ not done; - = tested negative; $+=$ tested positive, $+/$ - = only one DNA extraction method is positive. 
Table 6. Agreement of results between different methods for the detection of G. parasuis in clinical samples.

\begin{tabular}{|c|c|c|c|c|}
\hline \multicolumn{2}{|c|}{ Detection Method Used } & \multirow{2}{*}{$\begin{array}{c}\text { Agreement of Results } \\
\text { in } \%\end{array}$} & \multicolumn{2}{|c|}{ 95\% Confidence Intervals } \\
\hline Variable 1 & Variable 2 & & Lower & Upper \\
\hline $\begin{array}{l}\text { Culture-based } \\
\text { detection }\end{array}$ & $\begin{array}{l}\text { LAMP kit-extracted } \\
\text { DNA, undiluted }\end{array}$ & 77.1 & 59.9 & 89.6 \\
\hline $\begin{array}{c}\text { Culture-based } \\
\text { detection }\end{array}$ & $\begin{array}{l}\text { LAMP, heat-extracted } \\
\text { DNA, undiluted }\end{array}$ & 75.0 & 53.3 & 90.2 \\
\hline Conventional PCR & $\begin{array}{l}\text { LAMP kit-extracted } \\
\text { DNA, undiluted }\end{array}$ & 91.4 & 75.9 & 98.2 \\
\hline Conventional PCR & $\begin{array}{l}\text { LAMP, heat-extracted } \\
\text { DNA, undiluted }\end{array}$ & 95.8 & 78.9 & 99.9 \\
\hline $\begin{array}{l}\text { LAMP kit-extracted } \\
\text { DNA, undiluted }\end{array}$ & $\begin{array}{l}\text { LAMP kit-extracted } \\
\text { DNA, diluted 1:10 }\end{array}$ & 87.5 & 67.6 & 97.3 \\
\hline $\begin{array}{l}\text { LAMP, heat-extracted } \\
\text { DNA, undiluted }\end{array}$ & $\begin{array}{l}\text { LAMP kit-extracted } \\
\text { DNA, diluted 1:10 }\end{array}$ & 100 & 85.8 & 100 \\
\hline $\begin{array}{l}\text { LAMP kit-extracted } \\
\text { DNA, undiluted }\end{array}$ & $\begin{array}{l}\text { LAMP, heat-extracted } \\
\text { DNA, undiluted }\end{array}$ & 91.7 & 73.0 & 99.0 \\
\hline $\begin{array}{l}\text { Culture-based } \\
\text { detection }\end{array}$ & Conventional PCR & 85.7 & 69.7 & 95.2 \\
\hline
\end{tabular}

\section{Discussion}

Glaesserella (Haemophilus) parasuis is an important pathogen in the swine industry and rapid detection is key to controlling Glässer's disease and preventing possible outbreaks in herds. It is a sensitive fastidious pathogen dependent on nicotinamide adenine dinucleotide (NAD); therefore, its culture-dependent detection may not always be successful. In addition, culturing requires a relatively quick spread on growth media after sampling in order to maintain viability of the bacteria. Consequently, PCR-based methods provide many advantages in pathogen detection such as the possibility of storing samples for a longer period of time, quantification, or differentiation between morphologically indistinguishable species or genera.

In 2001, the first conventional PCR method for detecting Glaesserella (Haemophilus) parasuis was published [24]. For this assay, which targets a region of the $16 \mathrm{~S}$ ribosomal DNA gene, difficulties in distinguishing between G. parasuis and A. indolicus were reported. Thus, the assay was further developed and a modified version of the PCR with better specificity but worse sensitivity results was published in 2007. Currently, there are several PCR-based methods for detection of G. parasuis. However, these mostly require costly equipment that should be handled by experienced staff and is not easily transportable for field work. In 2000, a Japanese research team introduced a new detection method called loop-mediated isothermal amplification (LAMP) which amplifies DNA under isothermal conditions [23]. Some LAMP devices, such as the one used in this study, are portable devices that allow an ongoing run to be observed in real time and provide a melting temperature as a control. The device is equipped with a long-lasting battery and can be used off-grid directly in the field. Alternatively, a complete LAMP assay can be performed with a heat block only, allowing not only amplification, but also DNA heat extraction. The practical benefit of LAMP has already been confirmed by many previous studies $[42,43]$.

In the assay shown here, different target genes were evaluated. One primer set targeting the infB gene showed a very good performance, while the other primer set for the same target gene did not provide reliable differentiation between G. parasuis and Actinobacillus indolicus isolates. A second alternative target gene encoding $16 \mathrm{~S}$ rRNA was insufficiently specific to differentiate between G. parasuis and other closely related species, too. The inappropriateness of the 16S rRNA gene as the target gene was also described 
by Turni et al. (2010) [26]. The first approaches for detecting G. parasuis using the LAMP method have also been made. For example, Yang's research group developed and evaluated LAMP-based detection of G. parasuis targeting the 16S rRNA gene [32], but the inclusion of important controls such as the testing of closely related species, e.g., Actinobacillus indolicus and others, which must give negative results in the assay, was missing. Another study [34] also focused on establishing a LAMP assay for detecting G. parasuis, but did not include these negative controls either. Therefore, an assay should be developed here that allows this differentiation and which can also be used for clinical samples. The advantages that should result from the assay are shown in Table 7.

Table 7. The advantages of the developed LAMP assay.

\begin{tabular}{cc}
\hline Parameter & Availability for This Assay \\
\hline Primer concentration & Yes \\
Amplification temperature & Yes \\
Threshold & Yes \\
Real-time & Yes \\
Inclusion of the fifth and sixth (loop) primers & Yes \\
Inclusion of closely related species in the & Actinobacillus minor, Actinobacillus indolicus, \\
determination of analytical specificity & Actinobacillus porcinus, Actinobacillus arthritis \\
Analytical sensitivity & (among others) \\
Analytical specificity & 10 fg/ $\mu$ L DNA \\
Comparison of target genes & Yes \\
Comparison of DNA extraction methods & Yes \\
Detection in clinical field samples & Yes \\
Transportability to field & Yes \\
Reproducibility of the assay & Yes \\
\hline
\end{tabular}

The present assay correctly identified all 60 G. parasuis strains, including 14 different serotypes, and distinguished G. parasuis from all other tested species. Thus, it could be shown that the assay is $100 \%$ G. parasuis-specific. Particularly noteworthy is the successful differentiation of the assay between G. parasuis and A. indolicus, A. minor, A. arthritis, and A. porcinus due to the similarity in the target genome sequences and the previously reported problems in differentiation in other studies. This is of particular importance as these species also occur in pigs and colonize the upper respiratory tract.

During the establishment procedures, a temperature of $66^{\circ} \mathrm{C}$ with a run time of $45 \mathrm{~min}$ provided the fastest amplification. The comparison of two primer concentration variants showed a ten-fold difference in sensitivity in favor of a concentrated primer mix that detected a minimum of $10 \mathrm{fg} / \mu \mathrm{L}$. Yang et al. (2010) were able to detect positive G. parasuis only from $0.68 \mathrm{pg}$ pathogen DNA per microliter with their LAMP method. In addition, our test showed a low detection limit $\left(2.58 \times 10^{2}\right.$ cells $)$ in spiked BAL fluids. The methods developed by Yang et al. [32], Chen et al. [33], and Zhang et al. [34] achieved detection limits of $8 \mathrm{CFU} / \mathrm{mL}, 10 \mathrm{CFU} / \mathrm{mL}$, and five copies of DNA per tube, respectively. However, in none of these studies was BAL used as the spiking matrix and, therefore, no statement can be made concerning the suitability for direct detection from BAL fluids when using these methods. During the establishment of the LAMP assay, it was noticed that there were differences in the analytical sensitivity and the limit of detection between pure DNA detection and detection of cells in spiked $\mathrm{NaCl}$ or BAL fluids. These differences could be explained by the loss of DNA during isolation [44].

In this study, a second assay using a colorimetric master mix was tested and showed the same sensitivity for color-based detection of amplicons as in the case of amplification in a Genie ${ }^{\circledR}$ II device. This assay was performed to present an alternative option when working in the field. It offers easy detection via the naked eye when using one device, a heating block or a water bath, for DNA extraction and amplification of samples under isothermal conditions. Similar colorimetric assays developed for other pathogens showed 
promising results $[45,46]$. Nevertheless, visual positivity might be secondarily confirmed in the laboratory by gel electrophoresis.

The main LAMP assay was validated by analyzing 36 swabs from different organs and the results thereof were compared to two gold standards - the bacterial culture-based detection (performed at the Field Station for Epidemiology, Bakum, Germany) and conventional PCR as described earlier [24]. However, slight deviations in the results were detected. Two cultural microbiologically positive samples were negative in LAMP and PCR. Since direct pathogen detection from culture material was otherwise always reliable, it could have been the case here that the swabs did not contain bacteria, e.g., if they were taken from a location different from the one used for culture detection. In other five cases, negative samples from cultural microbiological detection were found to be LAMP-positive. However, this can easily be explained by high sensitivity and particular nutrient dependence of the pathogen, which often makes cultivation very difficult [32]. This assumption was confirmed in three cases by the use of a second DNA-based detection method, conventional PCR, which also showed a positive result. A further possibility is, of course, that only DNA was detected here and that the pathogen was no longer viable and therefore culturing could not be successful. This difference between culture-based detection and DNA-based detection has been reported many times, e.g., for Campylobacter spp. [47], Legionella spp. [48], or Streptococcus spp. [49]. However, two samples were LAMP-positive, whereas PCR remained negative. The reason could be the presence of PCR inhibitors in the samples or a contaminating background which influences one method more than the other. The research group of Lee et al. came to similar conclusions, whereby LAMP was more tolerant to PCR inhibitors than conventional PCR and therefore yielded better results [50].

During the testing of field samples, we also focused on the comparison of two DNA extraction methods. The isolation with a commercial kit showed more positive results and also faster detection times. Nevertheless, heat extraction in the field can be used as an alternative DNA extraction method, e.g., for screening.

In conclusion, this improved LAMP assay targeting a region of the infB gene for detection of G. parasuis presents a highly sensitive, rapid, and easy-to-handle method that can be used as a good alternative to other traditional methods.

Supplementary Materials: The following are available online at https:/ / www.mdpi.com/2076-260 7/9/1/41/s1, Table S1: Sequences of all the designed primer sets.

Author Contributions: Conceptualization: V.P., D.S., A.A., and C.K.; formal analysis: K.B.; investigation: V.P.; methodology: D.S., A.A., and C.K.; project administration: D.S. and C.K.; resources: I.H.-P., A.A., and C.K.; supervision: C.K.; validation: V.P., D.S., K.B., and C.K.; writing-original draft preparation: V.P., D.S., and C.K.; writing—review and editing: V.P., D.S., I.H.-P., K.B., A.A., and C.K. All authors have read and agreed to the published version of the manuscript.

Funding: This research received no external funding.

Data Availability Statement: The data presented in this study are available within this article or in the supplementary material (Table S1).

Acknowledgments: The authors would like to thank Katrin Strutzberg-Minder, Innovative Veterinary Diagnostics Laboratory (IVD), Seelze-Letter, Germany, for kindly providing some G. parasuis isolates for the study. Thanks also go to Inna Pahl, Iris Oltrogge, and Rouwen Stucke for their excellent technical assistance. This research received no external funding.

Conflicts of Interest: The authors declare no conflict of interest.

\section{References}

1. Dickerman, A.; Bandara, A.B.; Inzana, T.J. Phylogenomic analysis of Haemophilus parasuis and proposed reclassification to Glaesserella parasuis, gen. nov., comb. nov. Int. J. Syst. Evol. Microbiol. 2020, 70, 180-186. [CrossRef]

2. Kirkwood, R.; Rawluk, S.; Cegielski, A.; Otto, A.J. Effect of pig age and autogenous sow vaccination on nasal mucosal colonization of pigs by Haemophilus parasuis. Swine Health Prod. 2001, 9, 77-79.

3. Liu, S.; Li, W.; Wang, Y.; Gu, C.-Q.; Liu, X.; Charreyre, C.; Fan, S.; He, Q. Coinfection with Haemophilus parasuis serovar 4 increases the virulence of porcine circovirus type 2 in piglets. Virol. J. 2017, 14, 227. [CrossRef] 
4. Nedbalcová, K.; Šatrán, P.; Jaglic, Z.; Ondriasova, R.; Kucerova, Z. Haemophilus parasuis and Glässer's disease in pigs: A review. Vet. Med. 2006, 51, 168-179. [CrossRef]

5. Solano-Aguilar, G.I.; Pijoan, C.; Rapp-Gabrielson, V.; Collins, J.; Carvalho, L.F.; Winkelman, N. Protective role of maternal antibodies against Haemophilus parasuis infection. Am. J. Vet. Res. 1999, 60, 81-87. [PubMed]

6. Little, T.W. Haemophilus infection in pigs. Vet. Rec. 1970, 87, 399-402. [CrossRef] [PubMed]

7. Peet, R.L.; Fry, J.; Lloyd, J.; Henderson, J.; Curran, J.; Moir, D. Haemophilus parasuis septicaemia in pigs. Aust. Vet. J. 1983, 60, 187. [CrossRef] [PubMed]

8. Olvera, À.; Cerdag-Cuellar, M.; Mentaberre, G.; Casas-Díaz, E.; Lavín, S.; Marco, I.; Aragon, V. First isolation of Haemophilus parasuis and other NAD-dependent Pasteurellaceae of swine from European wild boars. Vet. Microbiol. 2007, 125, 182-186. [CrossRef]

9. Reiner, G.; Fresen, C.; Bronnert, S.; Haack, I.; Willems, H. Prevalence of Haemophilus parasuis infection in hunted wild boars (Sus scrofa) in Germany. Eur. J. Wildl. Res. 2010, 56, 815-818. [CrossRef]

10. Kielstein, P.; Rapp-Gabrielson, V.J. Designation of 15 serovars of Haemophilus parasuis on the basis of immunodiffusion using heat-stable antigen extracts. J. Clin. Microbiol. 1992, 30, 862-865. [CrossRef]

11. Ma, L.; Wang, L.; Chu, Y.; Li, X.; Cui, Y.; Chen, S.; Zhou, J.; Li, C.; Lu, Z.; Liu, J.; et al. Characterization of Chinese Haemophilus parasuis Isolates by Traditional Serotyping and Molecular Serotyping Methods. PLoS ONE 2016, 11, e0168903. [CrossRef] [PubMed]

12. Pires Espíndola, J.; Balbinott, N.; Trevisan Gressler, L.; Machado, G.; Silene Klein, C.; Rebelatto, R.; Gutiérrez Martín, C.B.; Kreutz, L.C.; Schryvers, A.B.; Frandoloso, R. Molecular serotyping of clinical strains of Haemophilus (Glaesserella) parasuis brings new insights regarding Glässer's disease outbreaks in Brazil. PeerJ 2019, 7, e6817. [CrossRef] [PubMed]

13. Rapp-Gabrielson, V.J.; Gabrielson, D.A.A. Prevalence of Haemophilus parasuis serovars among isolates from swine. Am. J. Vet. Res. 1992, 53, 659-664. [PubMed]

14. Tadjine, M.; Mittal, K.R.; Bourdon, S.; Gottschalk, M. Development of a New Serological Test for Serotyping Haemophilus parasuis Isolates and Determination of Their Prevalence in North America. J. Clin. Microbiol. 2004, 42, 839-840. [CrossRef]

15. Luppi, A.; Bonilauri, P.; Dottori, M.; Iodice, G.; Gherpelli, Y.; Merialdi, G.; Maioli, G.; Martelli, P. Haemophilus parasuis Serovars Isolated from Pathological Samples in Northern Italy. Transbound. Emerg. Dis. 2013, 60, 140-142. [CrossRef]

16. Angen, Ø.; Svensmark, B.; Mittal, K.R. Serological characterization of Danish Haemophilus parasuis isolates. Vet. Microbiol. 2004, 103, 255-258. [CrossRef]

17. Jia, A.; Zhou, R.; Fan, H.; Yang, K.; Zhang, J.; Xu, Y.; Wang, G.; Liao, M. Development of Serotype-Specific PCR Assays for Typing of Haemophilus parasuis Isolates Circulating in Southern China. J. Clin. Microbiol. 2017, 55, 3249-3257. [CrossRef]

18. Cai, X.; Chen, H.; Blackall, P.J.; Yin, Z.; Wang, L.; Liu, Z.; Jin, M. Serological characterization of Haemophilus parasuis isolates from China. Vet. Microbiol. 2005, 111, 231-236. [CrossRef]

19. Lin, W.-H.; Shih, H.-C.; Lin, C.-F.; Yang, C.-Y.; Chang, Y.-F.; Lin, C.-N.; Chiou, M.-T. Molecular serotyping of Haemophilus parasuis isolated from diseased pigs and the relationship between serovars and pathological patterns in Taiwan. PeerJ 2018, 6, e6017. [CrossRef]

20. Amano, H.; Shibata, M.; Kajio, N.; Morozumi, T. Pathologic Observations of Pigs Intranasally Inoculated with Serovar 1,4 and 5 of Haemophilus parasuis Using Immunoperoxidase Method. J. Vet. Med. Sci. 1994, 56, 639-644. [CrossRef]

21. Segalés, J.; Domingo, M.; Solano, G.I.; Pijoan, C. Immunohistochemical Detection of Haemophilus Parasuis Serovar 5 in FormalinFixed, Paraffin-Embedded Tissues of Experimentally Infected Swine. J. Vet. Diagn. Investig. 1997, 9, 237-243. [CrossRef] [PubMed]

22. Rafiee, M.; Blackall, P.J. Establishment, validation and use of the Kielstein-Rapp-Gabrielson serotyping scheme for Haemophilus parasuis. Aust. Vet. J. 2000, 78, 172-174. [CrossRef] [PubMed]

23. Angen, Ø.; Oliveira, S.; Ahrens, P.; Svensmark, B.; Leser, T.D. Development of an improved species specific PCR test for detection of Haemophilus parasuis. Vet. Microbiol. 2007, 119, 266-276. [CrossRef] [PubMed]

24. Oliveira, S.; Galina, L.; Pijoan, C. Development of a PCR test to diagnose Haemophilus parasuis infections. J. Vet. Diagn. Investig. 2001, 13, 495-501. [CrossRef] [PubMed]

25. Howell, K.J.; Weinert, L.A.; Langford, P.; Rycroft, A.N.; Wren, B.W.; Maskell, D.J.; Tucker, A.W.; Peters, S.E.; Wang, J.; HernandezGarcia, J.; et al. "Pathotyping" Multiplex PCR Assay for Haemophilus parasuis: A Tool for Prediction of Virulence. J. Clin. Microbiol. 2017, 55, 2617-2628. [CrossRef]

26. Turni, C.; Pyke, M.; Blackall, P.J. Validation of a real-time PCR for Haemophilus parasuis. J. Appl. Microbiol. 2010, 108, 1323-1331. [CrossRef]

27. Notomi, T.; Okayama, H.; Masubuchai, H.; Yonekawa, T.; Watanabe, K.; Amino, N.; Hase, T. Loop-mediated isothermal amplification (LAMP) of DNA. Nucleic Acids Res. 2000, 28, E63. [CrossRef]

28. Li, Y.; Fan, P.; Zhou, S.; Zhang, L. Loop-mediated isothermal amplification (LAMP): A novel rapid detection platform for pathogens. Microb. Pathog. 2017, 107, 54-61. [CrossRef]

29. Domesle, K.J.; Yang, Q.; Hammack, T.S.; Ge, B. Validation of a Salmonella loop-mediated isothermal amplification assay in animal food. Int. J. Food Microbiol. 2018, 264, 63-76. [CrossRef]

30. Da Silva, S.J.R.; Paiva, M.H.S.; Guedes, D.R.D.; Krokovsky, L.; De Melo, F.L.; Da Silva, M.A.L.; Da Silva, A.; Ayres, C.F.J.; Pena, L.J. Development and Validation of Reverse Transcription Loop-Mediated Isothermal Amplification (RT-LAMP) for Rapid Detection of ZIKV in Mosquito Samples from Brazil. Sci. Rep. 2019, 9, 4494. [CrossRef]

31. Zhang, Y.; Odiwuor, N.; Xiong, J.; Sun, L.; Nyaruaba, R.O.; Wei, H.; Tanner, N.A. Rapid Molecular Detection of SARS-CoV-2 (COVID-19) Virus RNA Using Colorimetric LAMP. medRxiv 2020. [CrossRef] 
32. Wang, Y.; Fang, Y.; Liu, Y.; Chen, P.; Li, W.; Liu, S.; Zou, H.; He, Q. Development and evaluation of loop-mediated isothermal amplification for rapid detection of Haemophilus parasuis. FEMS Microbiol. Lett. 2010, 313, 54-60. [CrossRef]

33. Chen, H.-T.; Chu, Y.-F.; Liu, Y.-S.; Zhang, J.; Lu, Z. Loop-mediated isothermal amplification for the rapid detection of Haemophilus parasuis. FEMS Immunol. Med. Microbiol. 2010, 60, 283-285. [CrossRef] [PubMed]

34. Zhang, J.-M.; Shen, H.-Y.; Liao, M.; Ren, T.; Guo, L.-L.; Xu, C.-G.; Feng, S.-X.; Fan, H.-Y.; Li, J.-Y.; Chen, J.-D.; et al. Detection of Haemophilus parasuis isolates from South China by loop-mediated isothermal amplification and isolate characterisation. Onderstepoort J. Vet. Res. 2012, 79, 6. [CrossRef]

35. Prüller, S.; Turni, C.; Blackall, P.J.; Beyerbach, M.; Klein, G.; Kreienbrock, L.; Strutzberg-Minder, K.; Kaspar, H.; Meemken, D.; Kehrenberg, C. Towards a Standardized Method for Broth Microdilution Susceptibility Testing of Haemophilus parasuis. J. Clin. Microbiol. 2017, 55, 264-273. [CrossRef]

36. Brogden, S.; Pavlović, A.; Tegeler, R.; Kaspar, H.; De Vaan, N.; Kehrenberg, C. Antimicrobial susceptibility of Haemophilus parasuis isolates from Germany by use of a proposed standard method for harmonized testing. Vet. Microbiol. 2018, 217, 32-35. [CrossRef]

37. Bisping, W.; Amtsberg, G. Colour Atlas for the Diagnosis of Bacterial Pathogens in Animals; Paul Parey Scientific Publishers: Berlin, Germany, 1988; p. 339.

38. Sange, M.D.; Becker, A.; Hassan, A.A.; Bülte, M.; Ganter, M.; Siebert, U.; Abdulmawjood, A. Development and validation of a loopmediated isothermal amplification assay-A rapid and sensitive detection tool for Mycobacterium avium subsp. paratuberculosis in small ruminants. J. Appl. Microbiol. 2019, 127, 47-58. [CrossRef]

39. AOAC. Guidelines for Standard Method Performance Requirements, 20th ed.; AOAC INTERNATIONAL: Rockville, MD, USA, 2016; Appendix F; p. 7.

40. $\quad$ SAS ${ }^{\circledR}$ Institute Inc. User's Guide (Release 9.4); SAS: Cary, NC, USA, 2013; Available online: https:/ / support.sas.com (accessed on 13 October 2020).

41. Koukos, G.; Papadopoulos, C.; Tsalikis, L.; Sakellari, D.; Arsenakis, M.; Konstantinidis, A. Prevalence of Antibiotic Resistance Genes in Subjects with Successful and Failing Dental Implants. A Pilot Study. Open Dent. J. 2015, 8, 257-263. [CrossRef]

42. Bath, C.; Scott, M.; Sharma, P.M.; Gurung, R.B.; Phuentshok, Y.; Pefanis, S.; Colling, A.; Balasubramanian, N.S.; Firestone, S.M.; Ungvanijban, S.; et al. Further development of a reverse-transcription loop-mediated isothermal amplification (RT-LAMP) assay for the detection of foot-and-mouth disease virus and validation in the field with use of an internal positive control. Transbound. Emerg. Dis. 2020, 67, 2494-2506. [CrossRef]

43. Best, N.; Rawlin, G.; Suter, R.; Rodoni, B.; Beddoe, T. Optimization of a Loop Mediated Isothermal Amplification (LAMP) Assay for In-Field Detection of Dichelobacter nodosus with aprV2 (VDN LAMP) in Victorian Sheep Flocks. Front. Vet. Sci. 2019, 6, 67. [CrossRef]

44. De Kok, J.B.; Hendriks, J.C.M.; Van Solinge, W.W.; Willems, H.L.; Mensink, E.J.; Swinkels, D.W. Use of Real-Time Quantitative PCR to Compare DNA Isolation Methods. Clin. Chem. 1998, 44, 2201-2204. [CrossRef] [PubMed]

45. Lai, M.-Y.; Ooi, C.-H.; Jaimin, J.J.; Lau, Y.-L. Evaluation of WarmStart Colorimetric Loop-Mediated Isothermal Amplification Assay for Diagnosis of Malaria. Am. J. Trop. Med. Hyg. 2020, 102, 1370-1372. [CrossRef] [PubMed]

46. Verma, G.; Sharma, S.; Raigond, B.; Pathania, S.; Naga, K.; Chakrabarti, S.K. Development and application of fluorescent loop mediated isothermal amplification technique to detect Phytophthora infestans from potato tubers targeting ITS-1 region. 3 Biotech 2019, 9, 345. [CrossRef] [PubMed]

47. Seinige, D.; Von Köckritz-Blickwede, M.; Krischek, C.; Klein, G.; Kehrenberg, C. Influencing Factors and Applicability of the Viability EMA-qPCR for a Detection and Quantification of Campylobacter Cells from Water Samples. PLoS ONE 2014, 9, e113812. [CrossRef]

48. Lund, V.; Fonahn, W.; Pettersen, J.E.; Caugant, D.A.; Ask, E.; Nysaeter, Å. Detection of Legionella by cultivation and quantitative real-time polymerase chain reaction in biological waste water treatment plants in Norway. J. Water Health 2014, 12, 543-554. [CrossRef]

49. Grønbaek, L.M.; Angen, Ø.; Vigre, H.; Olsen, S.N. Evaluation of a nested PCR test and bacterial culture of swabs from the nasal passages and from abscesses in relation to diagnosis of Streptococcus equi infection (strangles). Equine Vet. J. 2006, 38, 59-63. [CrossRef]

50. Lee, S.; Khoo, V.S.L.; Medriano, C.A.D.; Lee, T.; Park, S.-Y.; Bae, S. Rapid and in-situ detection of fecal indicator bacteria in water using simple DNA extraction and portable loop-mediated isothermal amplification (LAMP) PCR methods. Water Res. 2019, 160, 371-379. [CrossRef] 